\title{
LA POÉTICA DEBRAVIANA Y SU LEGADO A LA LITERATURA COSTARRICENSE
}

\author{
THE DEBRAVIAN POETRY AND ITS LEGACY TO COSTA RICAN LITERATURE**
}

\section{Evelyn Araya Fonseca*}

\section{RESUMEN}

Para aproximarse a la riqueza metafórica del discurso poético de Jorge Debravo es imprescindible efectuar un balance de lo que se ha escrito acerca de las motivaciones que impulsaron su proceso de creación artística. Por consiguiente, en este artículo se hace un recorrido por las historias de la literatura costarricense y por estudios sustentados en posiciones interpretativas que han adquirido cierta solidez con respeto al tema. Estos últimos, forman parte del crisol de lecturas que se ha ido construyendo desde hace más de cuatro decenios. Palabras clave: Historia literaria, literatura costarricense, poesía costarricense, Jorge Debravo.

\begin{abstract}
To approach to the metaphorical richness of Jorge Debravo's poetic discourse is essential to carry out a balance of what has been written about the motivations behind his artistic creation process. Therefore, this article makes a journey through the stories of the Costa Rican literature and research studies based on interpretive positions that have acquired some strength regarding the subject. These studies are part of the varied readings built for over four decades.
\end{abstract}

Key Words: literary history, Costa Rican literature, Costa Rican poetry, Jorge Debravo.

Magister en Literatura Latinoamericana. Asesora Nacional de Español del Departamento de I y II Ciclos del Ministerio de Educación Pública. Costa Rica.

** Traducción del título: Lic. Ana Patricia Quirós.

Correo electrónico: arafoneve@gmail.com

Recepción: 15/07/13. Aceptación: 12/09/13. 


\section{Introducción}

El análisis de las diversas líneas de pensamiento que han sido desarrolladas, tanto desde la crítica literaria como desde otros escenarios de la cultura costarricense es vital para un mejor acercamiento a la lírica debraviana. Y es que el corpus de lecturas de los textos de Jorge Debravo es vasto y heterogéneo y está conformado por comentarios vinculantes entre su vida y su obra, trabajos monográficos, estudios exegéticos-ya sea con respecto a un poema o a uno o más de sus poemarios,- crítica literaria e incluso trabajos que rastrean su visión teológica y humanista. Dentro de la variedad de estudios revisados, un alto porcentaje se respalda en la teoría semántico-estructural; pero también se presenta el análisis de tipo temáticoestilístico $\mathrm{y}$, en menor grado, algunos que se fundamentan en otras corrientes como por ejemplo la sociocrítica. Estos trabajos teóricos e interpretativos, que en palabras de Julio César Goyes Narváez confirman la importancia de la "crítica creativa" como "interpretación de la interpretación del mundo" "(2001:4), no solo han enriquecido un diálogo polifónico en torno a los textos del poeta sino que además han contribuido a institucionalizarlos ${ }^{2}$. De ahí la trascendencia de acercarse a esta Arte Poética y recoger sus ideas acerca de lo que define como poesía, poeta y poema y su visión acerca de las motivaciones que constituyen la esencia del acto creador.

La incursión en la historia de la literatura y en la crítica literaria se valora como la oportunidad de abrir un diálogo que enriquece y enmarca el fenómeno artístico. Dicha revisión permite establecer posibles conexiones que ubican, de manera más precisa, la producción poética estudiada entendiéndola como parte del devenir histórico y cultural de la nación y no como un hecho fortuito o aislado. De este modo se atiende el juicio de intelectuales que a lo largo de la segunda mitad del siglo XX y principios del XXI, reflexionaron sobre esta poética y su influencia dentro de las páginas de la vida cultural del país. Se ha optado por la revisión de las fuentes desde el punto de vista cronológico para así obtener una fotografía de la evolución del pensamiento en los casos en que se ha abordado la cosmovisión del escritor, así como la ubicación de su lírica dentro de corrientes o movimientos artísticos. Lo anterior, no sin antes presentar una síntesis de su cosecha creativa.

Luego de la especificación cronológica señalada, se abarcan brevemente tres temas que se entretejen o correlacionan en este discurso poético y que son un común denominador en la mayoría de las fuentes consultadas, aun cuando es preciso aclarar que muchas veces se valoran de forma mezclada, general y sucinta. Los tópicos globales propuestos para efectos de apreciación son los siguientes: el amor como fuerza regeneradora del universo, la presencia de Dios en la creación poética y la poesía como arma en la búsqueda de justicia social.

\section{Acerca del autor y su obra}

Sin lugar a dudas, y a pesar del paso del tiempo, el discurso poético de Jorge Debravo ha logrado enraizarse vigorosamente dentro de la historia de la literatura y de la identidad nacional. Muchas han sido las alusiones y comentarios con respecto a su vida fugaz, intensa, plagada de luces y sombras, una existencia física que se cerró tempranamente pero que dejó para siempre su voz resguardada en la palabra.

Las publicaciones de sus poemarios se extienden desde 1959, año en que Vórtices y Milagro $^{3}$ abierto salen a la luz pública ${ }^{4}$, hasta 1990 cuando a veintitrés años de su partida, se publica El grito más humano. Vórtices y Milagro abierto preceden a los siguientes textos: Bestiecillas plásticas (1960), Consejos para Cristo al comenzar el año (1960), Devocionario del amor sexual (1963), Poemas terrenales (1964), Digo (1965), Nosotros los hombres (1966) y Canciones cotidianas (1967). Todos los textos anteriores fueron publicados antes del deceso del poeta mientras que Los despiertos (1972), Otras cosas recogidas de la tierra (1981), Guerrilleros (1987) y El grito más humano (1990) constituyen parte de su obra inédita y póstuma. Cabe rescatar que Los despiertos se 
considera el último poemario que fue revisado por el autor antes de su muerte. El fervor por sistematizar y dar a conocer la obra del poeta fue también compartida por el escritor Joaquín Gutiérrez Mangel, quien se dio a la tarea de escribir el prólogo y seleccionar el material para la Antología mayor, compilación impresa por la Editorial Costa Rica en $1974^{5}$.

Todo lo anterior ha propiciado que, tanto dentro como fuera del país, haya sido recurrente la lectura y el estudio de uno o varios de los textos en mención. Debravo es uno de los poetas nacionales más leídos y también de los que más se ha escrito. La fértil cosecha que legó ha sido proporcional al nivel de interés que ha generado la indagación de aspectos en relación con su vida y, por supuesto, con su obra.

\section{Historias de la literatura y otros estudios}

Dentro del campo de los estudios historiográficos existen diversos espejos en los cuales el rostro de la lírica costarricense ha podido reflejarse a lo largo del tiempo. En este sentido es preciso hacer un recuento del aporte de estas propuestas, centradas en el interés por una periodización de nuestra poesía y especialmente por el establecimiento de referentes válidos para una mejor apreciación artística.

En 1959 la Editorial Universitaria publicó Historia de la Literatura Costarricense de don Abelardo Bonilla Baldares, libro reeditado en 1967 y en 1981. En esta amplia investigación se delinearon dos momentos cruciales dentro de la evolución de la literatura nacional: el período realista y la época contemporánea. El afianzamiento de ambas etapas se sustenta en cuatro períodos lingüísticos que representan visiones de mundo y panoramas culturales diferentes, experimentados por la nación a lo largo de su odisea ontológica: el colonial, el de la formación de la nacionalidad independiente, el de creación literaria propia de las cuatro primeras décadas del siglo XX y el contemporáneo. El pensador detalla que la época, que para entonces él denomina contemporánea, se basa en una nueva actitud en el cultivo de las letras y las artes plásticas y tiene como telón de fondo una revolución política donde la lucha por los derechos humanos se convierte en un tema capital. El florecimiento industrial y técnico que desde fines del siglo XIX y principios del XX había tomado ventaja en el país, trajo consigo la crudeza de problemas sociales como la desaparición de la pequeña propiedad, la explotación bananera y la presencia del siervo agrario. El tema social y político que desde años atrás se trataba en el ensayo, aflora en el cuento y la novela a partir de 1940 y le atribuye un nuevo aire, colmado de gran sensibilidad y libertad en el uso de las formas idiomáticas. Tal acontecimiento encendió el debate entre quienes hablaban de una literatura "comprometida" y aquellos que defendían la autonomía del arte ${ }^{6}$. En un contexto efervescente como el que se describe, la poesía era un género impopular que ni estaba al alcance ni se acercaba al gusto de los proletarios. Precisamente para este momento, Bonilla evita realizar predicciones o profundizar en la obra de los jóvenes del Círculo de poetas costarricenses y solamente hace alusión al autor de Nosotros los hombres como el más prometedor de una nueva generación y "el de mayor producción, mayor sencillez y mayores posibilidades" (1967:349).

El juicio de Bonilla, sería compartido por Carlos Rafael Duverrán quien en su libro Poesía Contemporánea de Costa Rica (1973) resalta a Debravo como una figura prominente de la Nueva Poesía de Costa Rica, escritura que, desde su óptica, abre surcos a partir de 1950 y deja atrás la fuerte presencia del modernismo que imperó a lo largo de toda la primera mitad del Siglo XX. Dicha apreciación es reforzada someramente por Virginia Sandoval de Fonseca en el texto Resumen de la Literatura Costarricense donde sitúa al artista dentro de la llamada poesía nueva: "Su expresión es vigorosa, penetrante. La intensidad de su decir poético, desde la emoción y con la emoción lo hace mostrarse humano y sincero."(1978: 176).

Alberto Baeza Flores en el laureado ensayo Evolución de la poesía costarricense, 
publicado en 1978, propone los siguientes cinco grupos de poetas: Generación del Modernismo y Posmodernismo (nacidos antes de 1899), Generación de poetas del Repertorio Americano (nacidos entre 1900 y 1915), Generación de poetas viajeros y de compromiso social (nacidos entre 1916 y 1930), Generación de Postguerra (nacidos entre 1931 y 1945) y la Nueva Poesía (1946 a $1965^{7}$ ). Llama la atención que de acuerdo con los parámetros descritos, Debravo sería producto de la Generación de Postguerra, marcada por el sacudimiento de conflictos bélicos que afectaron la totalidad del orbe (Guerra Civil Española, Segunda Guerra Mundial, entre otros) y la pequeña nación centroamericana en particular (crisis política que desemboca en la Guerra Civil de 1948). Con todo, Baeza elabora una metáfora que explica la evolución de la poesía como una línea ondulante donde confluyen factores "del espacio tiempo histórico que corresponden a distintos creadores y generaciones" (1978:13). De hecho lo ejemplifica precisamente con el caso de Debravo:

\begin{abstract}
Uno de los poetas fundamentales de la generación que califico de la Postguerra-el importante poeta Jorge Debravo (1938-1967), una de las voces líricas capitales en el panorama de la poesía costarricense de siempre-, no aparece desvinculado del proceso anterior en lo que éste significa participación de la emoción lírica desde el yo hacia el nosotros, con un lenguaje eminente por la comunicación, la firme transparencia y el fuerte vigor verbal (1978:13).
\end{abstract}

La propuesta creativa del poeta turrialbeño se vislumbra entonces para el investigador como un fruto del dolor y de la angustia de la postguerra, poesía que constituye "un diagnóstico sociopolítico y económico, sin que renuncie, en ningún momento a dejar de ser poesía." (Baeza, 1978: 13) Un año después, Jorge Valdeperas (1979) lo esbozaría en su libro Para una interpretación de la literatura costarricense donde apunta cómo el arte costarricense, y específicamente la literatura, se inclinó por mostrar una nueva perspectiva social en un contexto dinámico y sediento de humanismo. En medio de tan potente cambio, describe a Debravo como el "poeta indiscutido de la Costa Rica del futuro." Según Baeza, esa voz se cristaliza y toma fuerza cuando canta, pero también cuando resquebraja los artificios que limitan la verdadera comunión del ser humano con sus congéneres y con el universo:

El poeta no es sólo el que canta sino, también, el que se desencanta de falsos mitos, de equivocados símbolos, y señala nuevos horizontes en su fe en la creación, superior, humana.

(...) trasciende desde su yo personal hacia la onda universal. En este tránsito se descubre en él la condición de todos los hombres que coexisten y habitan en el poeta (1978:298).

$\mathrm{Y}$ es ante todo el hombre que encarna este alto sentido de la solidaridad quien, desde la trinchera del arte, se muestra como cantor, testigo y protagonista de una esperanza que se sostiene en la certeza de algo mejor que está por venir. Al respecto, Carlos Francisco Monge en su tesis de doctorado Códigos estéticos en la poesía de Costa Rica (1907-1967) propone el estudio de la configuración estético-discursiva de nuestra lírica y complementa muy atinadamente la noción de trovador que había sido trazada por Baeza: "El hombre — cantor que se configura en su poesía aprendió que la afirmación del mundo y de la historia consistía al mismo tiempo en replegarse ante la perversidad, y en manifestar la confianza en la humanidad" (1991: 415).

En su estudio, Monge (1991) postula la presencia de una poesía costarricense con dos períodos literarios claves e influyentes: el modernista, que nace con la literatura del país y cuyo dominio se prolonga aproximadamente hasta finales de la década de 1940 y la vanguardia, ideología que nace desde 1940 y se extiende hasta el momento de la escritura de su investigación. A diferencia de los académicos anteriores, dentro del período modernista señala tres generaciones: la modernista propiamente dicha, la posmodernista y la prevanguardista; mientras que a su juicio, la vanguardia presenta "la primera generación de vanguardia", "la segunda generación de vanguardia" y "la generación posvanguardista." Debravo forma parte del grupo de escritores nacidos entre 1938 y 1948 que en este caso conforman la posvanguardia. Junto a él, se destacan los nombres de: Laureano 
Albán, Alfonso Chase, Julieta Dobles, Mayra Jiménez, Marco Aguilar y Rodrigo Quirós. Se señala como un hallazgo fundamental de esta generación, la defensa del discurso poético como un testimonio y como una alocución de la historia que aspira a un realismo que ya se había consolidado en el género narrativo y que se nutre de un fuerte compromiso social que apunta a “(...) señalar la condición política de la realidad, y por ello en reconocer una función específica del ejercicio literario: testimoniar la historia, sin otra mediatización que la vehemencia y un conjunto básico de principios humanísticos" (1991:69).

Cabe subrayar que el estudio de Monge brinda un enfoque valioso al plantear la presencia de tejidos literarios que son agrupados en modalidades discursivas conocidas como códigos estéticos. Al mismo tiempo, el autor desmitifica la idea del posible retraso y aislamiento cultural de una lírica costarricense que, para algunos, creció ajena al ritmo de corrientes que tuvieron un fuerte impacto en el desarrollo del arte literario de la lengua española. Por ello, resalta el mérito de estudios que trascienden la revisión de influencias, movimientos o escuelas y que se abocan hacia la comprensión de las diferentes poéticas. Los códigos estéticos que propone son: el modernista, el posmodernista, el prevanguardista, la vanguardia y la poesía social $^{8}$. El discurso poético de Debravo se advierte no solo como parte esencial de este último código, sino también como el modelo más sólido que ofrece la historia de la poesía nacional al constituir "el ejemplo más coherente y compacto de esta modalidad" (1991:410). El investigador explica la presencia de una crítica al ensimismamiento y al fetichismo discursivo y una búsqueda afanosa por establecer una conexión con el lector. Dicha democratización de la lírica, pone la belleza de la palabra al alcance de todo aquel que desee acercarse y está por encima de intereses personales al considerar que "(...) el poema es un acto comunitario, y el poeta un develador del sentido del diario acontecer." (1991:44). De este modo, el discurso poético de Debravo se inscribe como un referente significativo en la construcción de la identidad nacional, imaginada por buena parte de los habitantes del país.

En consonancia con lo expuesto por Monge, Margarita Rojas y Flora Ovares hacen ver la trascendencia que ha tenido la práctica literaria para primero fundar y luego acrecentar la tradición costarricense. En su libro 100 años de literatura costarricense, las literatas retoman el realce que tuvo la publicación de la Lira costarricense en 1890 y 1891 y analizan que existe un enlace "entre el interés por recopilar y estudiar la literatura nacional y la afirmación de las particularidades de la sociedad propia. Esa definición de una literatura propia obedeció a criterios éticos y políticos locales, no solamente a criterios estéticos.” (1995:35). Más adelante, se refieren a la forma en que la literatura costarricense de las tres primeras décadas del siglo XX mostraría las veces de una nación abrumada por el conflicto y la desigualdad social. Como consecuencia, se daría el "rompimiento temporal del régimen democrático," experimentado por el país entre 1930 y 1950 a raíz de una tensa situación económica, avivada por los crueles enfrentamientos que azotaron al mundo durante la primera mitad del siglo. Así, es posible observar la variedad de derroteros por los que, a la altura de 1940, transitaban los diversos géneros literarios en nuestro país. Las estudiosas aclaran que mientras la realidad social era el tema por antonomasia en la narrativa, en el ensayo predominaba un pensamiento reflexivo, que centraba su atención en el papel de Costa Rica en el concierto de las naciones. Para estos años, la lírica se metamorfoseaba y fluía con alma propia. Su evolución se ratificaría durante las décadas de los años cincuentas y sesentas con la publicación de textos de gran realce, entre los que figuran los de Debravo:

(...) aparece en Costa Rica un tomo de poemas, Milagro abierto, que recoge parte de la producción lírica del poeta que iba a provocar una profunda innovación en la historia del género en el país. Jorge Debravo había iniciado esa renovación estética unos diez años antes, en libros como Devocionario del amor sexual (1963), Nosotros los hombres (1966) y Canciones cotidianas (1967). Tanto por las especiales circunstancias históricas y políticas como por varios rasgos del lenguaje 
poético (...) la poesía en estos años adquirió una alta difusión (1995:211).

En su texto, las autoras coinciden con los juicios que reflexionan acerca de la coherencia entre la faceta personal de este artista y su producción; al mismo tiempo, detallan que en sus escritos el rompimiento se consuma desde dos planos simbióticos: el contenido del mensaje y la forma en que este es presentado. $\mathrm{Al}$ respecto, señalan:

La significación histórica de Debravo y su popularidad deben explicarse no sólo por las rupturas que provocó en el plano de las nuevas temáticas de sus poemas sino también por la creación de un tipo nuevo de lenguaje lírico. Lógicamente ambos aspectos son inseparables y dependen uno de otro: la novedad de los significados exige nuevas formas de decirlo (1995:212).

La defensa de una propuesta utópica y la denuncia, esta última concebida como un trago amargo que debe saborearse si se quiere pagar el precio del cambio, son ingredientes de la poética debraviana atendidos por las investigadoras. En el capítulo "De la utopía al desencanto" se especifican innovaciones que sustentan la esperanza del poeta: la humanización de las imágenes religiosas y la afirmación de la unión sexual como un acto de comunión entre el ser humano y el universo. Según se especifica, el tratamiento de su poesía erótica es el que despierta mayor asombro, tanto por su actitud renovadora como por su alto grado de correspondencia con las ideas teológicas. De acuerdo con esa concepción el cuerpo, recinto del alma, es naturalmente puro, como toda la creación de Dios. El erotismo supera por mucho el mero acto carnal y se presenta como la forma sublime de expresión del amor, expresión que abraza todas las esferas de la vida porque en la vida, como en el universo, todo se encuentra interrelacionado:

La sexualidad no sólo se acepta como algo natural y positivo sino que además se glorifica. La actitud renovada frente al tema sexual se reafirma en la utilización de formas propias del habla religiosa para referirse a este tema (...).

Este es visto como sentimiento o actitud que va más allá de la relación de una pareja y que más bien se convierte en un principio moral y político. (...) El amor como solidaridad da paso al tema político y social enfocado desde una conciencia crítica frente al mundo. (1995:213).

De acuerdo con la cita anterior de Rojas y Ovares, la apoteosis del amor atraviesa los límites de la intimidad familiar y la esfera de lo religioso hasta tocar el nervio de lo político social. Erotismo, religión y justicia social forman la piedra angular que sostiene el discurso exteriorizado por el poeta.

Al referirse a los ejes de la poética, señalados anteriormente por las autoras, es primordial seguir volteando la mirada hacia acontecimientos de gran peso en el orden del devenir histórico de la nación. En su libro Breve historia de la literatura costarricense, publicado en el año 2000, Álvaro Quesada Soto recuerda el impacto que tuvo para el ambiente literario costarricense la caída de la república liberal cafetalera y la entrada en vigor de una reforma política y social:

Con la fundación en 1940 del Centro de Estudio de los Problemas Nacionales, de donde saldría más adelante el Partido Socialdemócrata, y con el ascenso al poder de Rafael A. Calderón Guardia (1940-1944), quien esboza en su primer mensaje presidencial el núcleo de lo que será la ideología social cristiana, se inicia la inserción del país en el nuevo orden político-ideológico internacional, y se cierra el ciclo del viejo liberalismo oligárquico. La guerra civil de 1948 y la nueva constitución de 1949, que reformaba tímidamente la vieja constitución de 1871, pero introducía un capítulo de "Garantías sociales" y otorgaba finalmente el voto a la mujer, marcaron el inicio de un nuevo período a partir de la década de 1950 (2000:55).

El arribo de los cambios señalados, trae consigo la ruptura de esquemas tradicionales y de viejos moldes de pensamiento, lo cual abona el terreno para que a partir de la década de 1960, se dé lo que Quesada Soto denominaría "un renacer en la literatura costarricense." El autor formula que son dos las agrupaciones de autores influyentes de la época, si se sopesan sus edades y su formación ideológica y literaria. Cada grupo representa una vocación estéticaideológica; sin embargo, señala además que ambas líneas son oscilantes, se cruzan y se 
nutren entre sí. La primera muestra una óptica "más subjetiva, hermética o autorreferencial" y la segunda está más orientada hacia "la denuncia, o la referencia a la realidad social y las transformaciones históricas, preocupada por la recepción y la accesibilidad a un público más amplio" (2000:78). Dentro del primer grupo, simultáneo al proyecto modernizador de la "Segunda República", aparecen los nombres de los poetas: Arturo Montero Vega, Alfredo Sancho, Mario Picado, Virginia Grutter, Jorge Charpantier, Ana Antillón y Carlos Rafael Duverrán. Entretanto, la segunda tendencia, testigo de "las transformaciones ideológicas y culturales ligadas a la Revolución Cubana y las revueltas estudiantiles y juveniles" (2000:79), dispone de los siguientes autores líricos: Jorge Debravo, Mayra Jiménez, Laureano Albán, Julieta Dobles Yzaguirre, Rodrigo Quirós, Alfonso Chase y Carlos de la Ossa. De acuerdo con Quesada, Debravo dio un gran impulso al segundo tipo de literatura durante los años sesenta y setenta:

El predominio de la segunda línea sobre la primera en esos últimos años se puede atribuir al entusiasmo revolucionario de la época como al influjo determinante de Jorge Debravo, quien (...) logró convertirse en el poeta más influyente y el de mayor difusión en la historia de la poesía costarricense (2000:78).

Justamente el poeta se consolidaría como el exponente por excelencia o el "modelo paradigmático" de un estilo que critica los viejos ropajes discursivos, que apuesta por la experimentación y ansía un canal más abierto para interactuar con el lector:

De aquí que abunden en estos textos las palabras que remiten a lo elemental, vital y puro, como el aire, el pan, el agua, la tierra; de aquí que sea frecuente en ellos el tópico de la revolución como emancipación de los valores de cambio mercantiles, las relaciones de propiedad y la explotación, y la afirmación utópica de un mundo regido por los valores de uso, el amor, el trabajo, la fraternidad (2000:78).

Por otra parte, Francisco Rodríguez Cascante muestra una radiografía diferente en relación con el origen y el desarrollo de la poesía costarricense. Desde su punto de vista, nuestra lírica está edificada sobre dos grandes formaciones discursivas: la trascendentalista, enraizada en la estética romántica y modernista de fines del siglo XIX y principios del XX y la conversacional, con una fuerte presencia a partir de la segunda mitad del siglo XX.

Según el crítico, la poesía conversacional (término acuñado por Roberto Fernández Retamar) designada por otros como "existencial," "antipoesía" o "exteriorismo," tomó su propio sendero y se ha prolongado hasta la actualidad. Esta poesía despliega un abanico de cinco poéticas que dialogan y se cruzan entre sí, a saber: la de énfasis individualista, ligada a la narratividad del mundo cotidiano, de análisis social, de énfasis metapoético y culturalista, de carácter feminista y, finalmente, la de tópico amatorio.

Dentro del contenido de la poesía conversacional destacan los temas marginales y los de una honda preocupación por el ámbito político; del mismo modo, la caracteriza la inclinación por la narratividad y el verso libre, aunque en el caso de Debravo, se evidencia la predilección por el cuidado de las formas tradicionales ${ }^{10}$. En su artículo "La poesía costarricense contemporánea y el campo discursivo conversacional" incluido en la Revista Káñina, el especialista subraya el peso que tiene el trabajo de Debravo en el desarrollo de la poesía conversacional del país: "La poesía conversacional de análisis social, ha tenido gran trayectoria en Costa Rica, fundamentalmente por la escritura de Jorge Debravo" (2006:151).

Rodríguez expresa que nuestra historiografía literaria ${ }^{11}$, tradicionalmente lineal y positivista, debe remozarse y proponer lecturas que rastreen, no solo las constantes discursivas, sino también las rupturas y los vacíos evidenciados en los textos literarios. La tarea ineludible radicaría, y en esto coincide con Carlos Francisco Monge, en ir más allá de indagaciones que sigan creciendo a la sombra de referentes de tipo biográfico o cronológico. 


\subsection{El amor como fuerza regeneradora del universo}

La temática del amor es una constante que se expande y ramifica para detentar un papel sobresaliente a lo largo de toda la producción de Jorge Debravo. La presencia del amor se ha abordado desde diversas perspectivas: amor carnal, amor por los hijos, amor por la naturaleza, amor por las cosas, amor por la humanidad.

Es en los poemas de Debravo, y ante todo en su Devocionario del amor sexual y en Poemas Terrenales, donde el amor carnal o erótico encuentra el terreno próspero para germinar; por ejemplo, Virginia Sandoval de Fonseca (1978) resaltaría la manera en que este elemento atraviesa gran parte de su obra. El juicio es relevante, sobre todo si se recuerda que ciertamente nuestra poesía alcanza una nueva forma de expresión del erotismo, lo cual le concede un aire distinto y pone en la palestra los prejuicios sociales imperantes, arraigados en una sociedad tradicional y conservadora.

En la antología El amor en la poesía costarricense, Alfonso Chase destaca la aventura hacia el descubrimiento milagroso del cuerpo como receptáculo de un amor embriagador. Chase se aproxima al magistral tratamiento del tema del amor erótico en el Devocionario del amor sexual y comenta este aspecto medular de su poética:

(...) Lo extraordinario en este pequeño libro estructurado en sus cuarenta y cinco poemas, es que resume, en un poeta inicial, el sentido del amor como un acto de búsqueda, de cortesía, de viaje, de descubrimiento del cuerpo propio y el de la amada, por el que ésta se convierte en amante, esposa, metáfora, poema mismo, concepción sinfónica en la cual la integración del universo, mística y gozosa manera de estar enamorado, hace de la dialéctica de los instintos la piedra angular de la fundación de una cultura literaria en la expresión del amor, (...) (2000:32).

Otro aspecto que se advierte en diversos comentarios, radica en la mezcla del amor con otros sentimientos apabullantes como la angustia y la muerte. En su libro Poesía en Jorge Debravo, Yadira Calvo Fajardo afirma que el sujeto lírico comúnmente opone o parea el amor con la muerte. Calvo manifiesta en su análisis estilístico y estructural que, como consecuencia de la circularidad de la vida, en esta literatura los extremos amor-muerte constantemente se atraen y se alejan para dejar entrever a un yo lírico contradictorio, entrañablemente humano. Para la ensayista, hay virtud en la construcción de un amor palpable, anclado en un lenguaje sencillo que lo vuelve auténtico pues "Todo es medible y ubicable en su mundo poético, hasta el amor y el sufrimiento, el deseo y la muerte, lo inasible, lo etéreo" (1980: 258). El amor se ensancha y se vuelve accesible a todas las personas, es un amor que por genuinamente humano, adquiere carácter universal:

La gran fuerza de su palabra poética deriva de su sencillez, de la naturaleza comulgatoria de una poesía de visión colectiva que se levanta como la voz profética de las bienaventuranzas, para introducir al hombre a la hermandad y al amor a todos "y hacia todo, amor cosmológico, universal. Su poesía logra esto recurriendo a la inclusión de elementos que la acercan al lenguaje de todas las gentes (...) (1980:259).

La aseveración es compartida por María Salvadora Ortiz, autora del artículo "La fraternidad del yo lírico en Canciones cotidianas de Jorge Debravo," que se da a conocer en 1987 en la Revista de Filología y Lingüística. Por medio de un análisis de las isotopías semánticas propuestas para la lectura del poemario, Ortiz concluye en su estudio que el alto grado de comunicación que se determina en la poesía debraviana es motivado por un diálogo entre el "Amor" como "Destinador" y la "Humanidad" como "Destinatario" (1987:44). La conclusión es significativa ya que según la lectura es el "Amor" mismo el que en la más grandiosa extensión de la palabra, se convierte en el artífice de un mensaje que, por intenso y emotivo, rebasa límites insospechados. De este modo, el mensaje llega a un lector que no se siente aislado ya que halla las ligaduras invisibles que lo hermanan con el resto del conglomerado social y que, finalmente, le dan un sentido de pertenencia. 


\subsection{La presencia de Dios en la creación poética}

El tratamiento de la figura de Dios en la obra del poeta ha sido uno de los aspectos que ha despertado mayor interés. Multiplicidad de comentarios reafirman la relevancia del tema teológico como un asunto de primer orden; sin embargo, en este apartado se hará revisión de tres trabajos que centran sus expectativas en la producción religiosa del turrialbeño. Primeramente se hará alusión a la tesis de doctorado de la Universidad Complutense de Madrid titulada: Tres caminos y nueve voces en la poesía religiosa hispanoamericana contemporánea de Juan Manuel Martínez Fernández. En la investigación, Martínez Fernández explica que la creación religiosa de Debravo abarca casi toda su obra y ubica su voz como una de las más sobresalientes dentro de la poesía religiosa hispanoamericana ${ }^{12}$.

Según su planteamiento, el sujeto lírico manifiesta cuatro formas de relacionarse con Dios: el intimismo, lo religioso-social, el franciscanismo y lo erótico sexual ${ }^{13}$. De las anteriores, la de índole erótico sexual, que presenta a la amada como el receptáculo de amor que le permite al poeta experimentar una mayor alianza con la vida y con Dios, se subraya como el aporte teológico de mayor riqueza y potencial creativo. Tales formas de acercarse a Dios, muchas veces se fusionan y su origen estaría en lo que el autor denomina "fe/ creencia no desarrollada, recibida como sustrato en la infancia" (Martínez, 2005: 577). Esta condición de fe se metamorfosea en las aguas del transcurrir de la experiencia y sacude el estado de ánimo del poeta, quien soporta una fuerte lucha interior. Es así como la relación cercana y constante con esta Fuerza Superior evoluciona hasta convertirse en un intenso compromiso existencial:

(...) la relación de Dios con Debravo sigue una línea evolutiva que va desde la intimidad y referencialidad de la infancia y los consejos de la fraternidad, hasta la duda primero y la negación y acusación después ante la no superación de un doble problema: el personal de la muerte, y el social del dolor. (...) esa relación con Dios no era ni tan profunda ni tan fuerte como para haber madurado con el poeta. Como a Vallejo, la fe infantil, el Dios de la infancia, se le quedó pequeño y lo que hace Debravo, en el mejor de los casos es reconstruirse y reconstruir a Dios (...) (Martínez, 2005: 552).

El sentimiento tiñe de desgarradoras imágenes los versos ${ }^{14}$ del costarricense y hace inevitable la comparación con César Vallejo, no sin resaltar que la poesía del turrialbeño sigue su propio rumbo y que hay una gran diferencia entre ambas poéticas: "Debravo llega a la queja y a la crítica, no a la blasfemia; la expresión de dolor es de imaginería más plásticamente infantil, más diluida y de menor fuerza patética." (Martínez, 2005:544). De acuerdo con la investigación, el motivo religioso o espiritual se cristaliza a partir de cuatro puntos claves que muchas veces se funden en la fragua de los versos: Dios, la amada, el sexo y la muerte.

Por otro lado, tanto la angustia generada por la conciencia de la injusticia así como el dolor que asolan el alma, propician que el diálogo con Cristo se trueque por un espíritu revolucionario que responda a una realidad atroz. La poesía es entonces una solución, un acicate para mantenerse en vigilia y pie de lucha.

El segundo aporte es el de Edmundo Retana Jiménez quien en su artículo "Imágenes liberadoras de Dios en la poesía de Jorge Debravo," editado en el 2006 por la revista Pasos número 125, se detiene a examinar la estrecha relación que existe entre la poesía y la Teología y, en el caso de América Latina y el Caribe, entre la poesía y la Teología de la Liberación. Esta reciprocidad se sostiene porque el misterio de la existencia de Dios y su relación con los seres humanos, no puede explicarse solo desde un lenguaje racional o lógico, antes bien, brota del caudal infinito del lenguaje simbólico. De este modo, la literatura se valoraría como una fuente de imágenes orgánicas que evolucionan y enriquecen la Teología, campo que se detiene a examinar los vínculos que se establecen entre los seres humanos y Dios.

La poética en estudio es un ejemplo de "la búsqueda de una visión personal de Dios" (Retana, 2006: 3). El Dios que Martínez había 
consignado como una reminiscencia de la niñez, el que se presenta en Consejos para Cristo al comenzar el año, es también señalado por Retana como un "Dios heredado" y "proyectado desde cierta imaginería popular." (Retana: 2005: 3). Pero este modo de ver a Dios se modifica y va, desde la interrogación constante, hasta una búsqueda en medio de la oscuridad. Dios es entonces misterioso, desconocido, una flecha en el vacío que, al no acudir al llamado, ocasiona una sensación de orfandad y ausencia. Según Retana, estas visiones fluctúan y se experimenta un abandono porque Dios está lejos del dolor humano, de la opresión y del sufrimiento. De ahí que el poeta rompa con la visión anquilosada e idólatra del Dios tradicional:

Esta ruptura con los dioses, que es en el fondo un rompimiento con el Dios tradicional, lleva al autor a reinterpretar los códigos de la religiosidad de su entorno desde una perspectiva desacralizadora. Expresa de este modo su crítica profunda y radical a ciertas maneras tradicionales de asumir la fe, en búsqueda de una manera de creer en Dios y, al mismo tiempo, en la lucha de los seres humanos: (...) No le gusta al poeta una religiosidad que aleje de la lucha y la protesta, tampoco quiere que, desde supuestas prácticas de fe, se engañe a la gente (Retana, 2006:5).

La ruptura acarrea un redescubrimiento de la forma de sentir a Dios. El poeta encuentra dentro de sí la presencia de lo sobrenatural y construye un discurso poético de la fe. Tal "redescubrimiento de Dios," que ahora encuentra en su misma carne, conlleva una nueva forma de creer, un penetrante proceso de reflexión y una crítica contra la pasividad. Asimismo, aboga por personas que vivan la fe desde la acción, las ideas y los proyectos, tal y como se comprende desde la Teología de la Liberación:

Es importante hacer notar que la imagen de Dios que Debravo forjó progresivamente en sus escritos, a partir de su crítica social y religiosa, tiene similitud con el Dios de la vida y de la historia que la Teología de la Liberación construyó a lo largo de su nacimiento y desarrollo. (...) tanto la Teología de la Liberación como la obra poética de Debravo tienen como trasfondo social e histórico las agitadas décadas de los sesentas y los setentas en Latinoamérica y el Caribe, a las cuales responden desde imágenes de Dios liberadoras. (Retana, 2006: 9).
El tercer estudio es un artículo publicado en la Revista Káñina y se titula "La buena noticia para los hombres: las bienaventuranzas según Jorge Debravo," escrito por el académico Jorge Chen Sham. En el análisis se profundiza en cuanto a la condensación de ideas que subyacen en el poema "Esa hora nueva" y se le da relieve a la actitud activa que ha de tener el sujeto cristiano frente a los actos de injusticia que marcan el curso de los acontecimientos históricos y sociales. Ante ello el artista, voz profética, asume un compromiso hic et nunc:

\footnotetext{
De este modo, el hablante lírico se hace eco de esa tradición que se remonta a los profetas del Antiguo Testamento; estos anunciaban la buena noticia de la liberación y redención del pueblo judío, que Jesús actualiza en el Nuevo Testamento a través de las Bienaventuranzas y que, en Nosotros los hombres, vuelve a asumir este sujeto que se representa también como mensajero y testimonio, es decir, como un nuevo profeta que anuncia y denuncia (Chen, 1998: 25).
}

Se hace notar, finalmente, la manera en que el tema teológico adquiere grandes dimensiones en la construcción del discurso poético de Debravo. En el marco de sus propias inquietudes existenciales y estéticas, el poeta humaniza a Dios, se convierte en mensajero de las bienaventuranzas y confía en un acercamiento a esta figura desde la acción y la verdadera práctica de los preceptos cristianos.

\subsection{La poesía como arma en la búsqueda de justicia social}

En el 2007, durante la conmemoración de los cuarenta años de la muerte del poeta, la Revista Comunicación de la Escuela de Ciencias del Lenguaje del Instituto Tecnológico de Costa Rica, le rinde homenaje y publica una serie de artículos biográficos y de análisis. En la información, aparecen diversos textos de escritores, allegados y especialistas en estudios literarios que examinan la obra del vate. El conjunto de voces que se escuchan, acercan al lector a las calidades humanas del artista y a su urgencia por traducir esa sensibilidad en hechos concretos. Del homenaje se rescatan tres 
artículos en los que, desde diversos ángulos, se reflexiona con respecto a uno de los aspectos más comentados de la obra del autor: la búsqueda de justicia social.

Primeramente, Óscar Montanaro Meza en "La vigencia poética de Jorge Debravo" acentúa la solidaridad como idea inevitable en la construcción del discurso poético estudiado. Tal virtud, se entronca con el sufrimiento que experimenta el artista al ser testigo de distintas formas de opresión. Montanaro alega que la esperanza de un mundo mejor es la sustancia con la que se construye el poema, el ejercicio de creación artística cobra sentido porque la palabra es "la materia instrumento del poema, de la canción, proclama la misión del poeta, que con su trabajo anhela el amor, la lucha por la paz y en definitiva, la fraternidad entre los seres humanos." (2007:56)

La conferencia de Francisco Rodríguez Cascante titulada "La poesía de Jorge Debravo y el pensamiento humanístico" concuerda con los planteamientos que resaltan el fuerte llamado de la voz debraviana y la posición profética que asume como guía de los oprimidos. Desde este ángulo, el grado superlativo de comunicabilidad tiene su influjo en un humanismo beligerante, pletórico de espiritualidad, que permite tender puentes entre el poeta y un lector que se vuelve más participativo. Como parte de esta ideología, Rodríguez comenta acerca de Nosotros los hombres:

(...) representa las contradicciones sociales con mayor ahínco y en términos socio-políticos: la pobreza, la injusticia, la degradación del ser humano, pero al lado de un llamado por la transformación social, por la necesidad de luchar por mejorar las condiciones de existencia de la humanidad. Ante ello, propone en primera instancia la denuncia, para que esta sea una toma de conciencia, y posterior a ella, devenga la lucha (...) (2007:70).

En el artículo se resalta que el afán de justicia, sobre todo en pro de los pobres, es totalmente congruente con la Teología de la Liberación, cuya base ideológica se condensa en la Biblia y en la corriente marxista pues, para el autor "No se trata de una escritura neutra, sino de un trabajo de producción textual que ha tomado partido y como sabemos, en el caso de Debravo es al lado de los más humildes y necesitados." (Rodríguez, 2007: 72).

Otro punto importante es la potencia de esta voz que se consolida, no solo por el mensaje afincado en el discurso, sino también por la magistral mediación de un lenguaje propio de la poesía conversacional. El proyecto social está inserto en su lírica porque el "yo" existe y cobra relevancia en tanto se piense en el bienestar de los demás.

Por otra parte, Magda Brenes Papayorgo en "La intertextualidad en la poética de Jorge Debravo," plantea una relación dialógica entre la poesía y el entorno socioeconómico e histórico costarricense y latinoamericano. Dicho carácter intertextual privilegia la atención del sujeto lírico frente a las carencias sociales y las limitaciones de los desposeídos:

Es un sujeto de la escritura que es consciente
de la problemática que lee en el contexto, no
sólo la problemática agraria de la tierra en pocas
manos, sino la problemática social de la inadecuada
distribución de la riqueza (pan) y la falta de amor y
de trabajo a muchos seres humanos (...) (2007:76).

De esta forma se concluye que, pesar del paso del tiempo, el tópico continúa vigente, absolutamente ubicado en el medio actual. En definitiva, se trata del arte que alcanza la inmortalidad no sólo porque conserva la frescura de un sello único, sino también por ser una literatura que no se queda en la crítica y que pondera soluciones urgentes que provengan de espíritus profusamente revolucionarios.

\section{Conclusiones}

Una vez efectuado el recuento de las valoraciones emitidas con respecto a la obra de Jorge Debravo, se constata la importancia que, a pesar del transcurrir del tiempo, sigue detentando la palabra del poeta. Prueba contundente de lo anterior es el juicio que emiten los especialistas desde el inicio de los pasos del autor en el ejercicio de la escritura. Tales ideas se sostienen, legitiman y reproducen a lo largo de las últimas décadas del siglo e incluso, en los albores del 
nuevo milenio, estudiosos como Álvaro Quesada Soto y Francisco Rodríguez Cascante ratifican el peso que ostenta dicha propuesta en nuestra historia literaria. El primero, lo cataloga como el poeta más influyente y el de mayor difusión en la historia del país; el segundo, como el impulsor del cultivo y desarrollo de la poesía conversacional.

Por otro lado, es necesario apuntar que aun cuando dentro de los estudios aparecen ciertas divergencias a la hora de situar la producción de Debravo en un período definido, evidentemente sobresalen líneas en común en cuanto a los motivos históricos sociales y políticos que pudieron haber propiciado un giro en la manera en que se comenzó a escribir poesía a mediados del siglo $\mathrm{XX}$. Y es que, tanto por las circunstancias nacionales como por el efecto indirecto de los hechos internacionales, se respiraba una atmósfera de contrastes en una nación que era azotada por la desigualdad y al mismo tiempo acariciada por la esperanza. De ahí que la poesía de Debravo se establezca como signo de una época de cambios que se inicia en la década de 1950 y se consolida en la de 1960. Cabe agregar que los años cuarenta revelan la preponderancia alcanzada por el realismo en la narrativa costarricense y su impacto en el campo de la lírica. Ello justifica, en buena medida, la innovación en el uso del lenguaje, la búsqueda de comunicabilidad y la profunda veta social que caracterizan el discurso poético en estudio. Con todo, la gestación de dicho espíritu es mucho más subterránea, yace en la entraña misma de la historia y de la cultura nacional desde donde finalmente ha irrumpido para convertirse en un ícono del arte latinoamericano.

Las historias de la literatura ofrecen variedad de comentarios y estudios en torno a la biografía y la obra de Jorge Debravo; no obstante, se observa la importancia de realizar una lectura de las enunciaciones implícitas y explícitas centrándose en el Arte Poética que entreteje su discurso. También fue posible revisar los juicios desde el lente de tres ámbitos temáticos reiterativos en la multiplicidad de fuentes consultadas: el amor, la presencia de Dios y la justicia social. Dichas esferas se intersecan y fundan un espacio de encrucijada donde anida el enigma de la poesía.

$\mathrm{Si}$ para Bonilla es probable que en ningún otro país como en Costa Rica sea más atinado decir que la sociedad es producto de las letras, bien se puede asegurar que la poesía del turrialbeño, no solo forma parte del patrimonio cultural del país sino que lo ha dotado de recursos para su construcción. El legado de Debravo significa, como lo significaron otros escritores en su época, una necesidad histórica de la nación que al mismo tiempo se convirtió en un triunfo del arte universal.

\section{Notas}

1. En su artículo "La fractura crítica-creación", el autor hace referencia al reto de una dinámica interpretativa que se atreva a la "búsqueda artística" y que recurra a la "dialogía poética (...) desde y en lo poético mismo" para luego trascender hacia "esferas interdisciplinarias" que acrecienten el conocimiento vivo.

2. Jorge Chen Sham señala en el artículo "La silenciosa incertidumbre de la Lira Costarricense: un acercamiento a su proceso de recepción" de la Revista de Filología, Lingüística y Literatura, (1996:19) que existe una tendencia discursiva que identifica como una "deriva hermenéutica no consciente" y que en nuestro país ha inclinado la balanza hacia el estudio de la narrativa, instaurando así, silencios apabullantes en torno al género lírico. Chen examina el caso de la Lira Costarricense como un ejemplo contundente, ya que a pesar de ser reconocida como la primera antología poética del país, desde su publicación en 1890 y hasta la época contemporánea, se ha ubicado en la periferia de los "códigos de aceptabilidad". Al respecto apunta a que el tema de la institucionalidad se analice sociológicamente pues un texto pasa a ser "monumental" y "consagrado", por el peso de los comentarios críticos y en la mayoría de los casos también escolares, así se explica la "necesidad del texto por legitimarse con glosas impuestas a él". En concordancia con lo expuesto, la tesis Jorge Debravo, legitimación y permanencia, defendida por Magda María Brenes Papayorgo en 1990 constituye una fuente importante donde se plantea la vigencia e institucionalización como producto de la comunicación poética. Para la propuesta, es fundamental la recopilación y lectura de textos orales y escritos en torno a la vida y obra del vate. 
3. En esta tesis los usos de mayúscula, originalmente utilizados en la escritura de los nombres de los textos, fueron variados para que se ajusten a lo dictado por la Ortografía de la lengua española, publicada recientemente.

4. Aunque este es el período que se registra como el inicio de la publicación de su obra, debe destacarse el esfuerzo previo del artista por proyectar su literatura y la de sus contemporáneos en el periódico El turrialbeño. Tiempo después, también lo hizo en alianza con los compañeros del Círculo de poetas de Turrialba, que fundó junto a Marco Aguilar y Laureano Albán. De hecho, en un inicio, el recurso utilizado por el grupo para difundir su lírica fue un mimeógrafo facilitado por la municipalidad del cantón. El conjunto de textos publicados se dio a conocer con el nombre de Biblioteca Lineas Grises.

5. Años más tarde, otro gran poeta e intelectual costarricense, Isaac Felipe Azofeifa, incursionaría en la recopilación y estudio del poemario Otras cosas recogidas de la tierra.

6. Para Bonilla la controversia es innecesaria pues el texto literario adquiere valor por su universalidad, fuerza evocadora o por su estilo y, a pesar de que el escritor desee denunciar de manera objetiva, la ideología personal desaparece con el nacimiento de la obra artística.

7. Resulta de interés detallar que, dentro de la taxonomía propuesta por el autor, la última generación es catalogada como "incompleta" pues, para el momento de la escritura del ensayo, los más jóvenes del grupo (de unos doce años de edad) no habían podido desarrollar y dar a conocer su obra.

8. En su tesis, Carlos Francisco Monge también especifica los conjuntos temáticos que considera vitales para la conformación de la poesía social en Costa Rica: la historia inmediata como entorno ontológico, la ética de la solidaridad y la vuelta a lo elemental. Como se verá más adelante, estos tres ejes coinciden con el enraizamiento de un agudo existencialismo, la influencia de ideas de la Teología de la Liberación y las imágenes genésicas y los elementos contrarios que presenta la poesía de Debravo.

9. El modo explícito en que se aborda el erotismo en los poemas de este escritor permite ver desde una nueva óptica la figura femenina. Dicha renovación de la dinámica de la mujer se hace notoria pues, tal y como lo explica Álvaro Quesada Soto en Breve historia de la literatura costarricense, durante las décadas anteriores, y específicamente en textos de la Generación del Olimpo, el placer sexual se visualizó como un tema amenazante del orden social. En estos textos, la mujer se presenta estigmatizada por el desequilibrio de la histeria y/o la neurosis y arrastra todo a su paso hacia la desmesura y la perdición.

10. Francisco Zúñiga Díaz en su libro El soneto en la poesía costarricense (1979:19) indica la relevancia que ha cobrado esta estructura en la creación de la lírica nacional. Zúñiga hace hincapié en los inicios del soneto que se remontan a la segunda mitad del siglo XIII cuando es creado por Jacobo Da Lentini. Tiempo después, el soneto es reafirmado literariamente por Guido Gunezelli y por Petrarca. Jorge Debravo fue uno los exponentes de la lírica costarricense que se inclinó, en muchas ocasiones, por esta arquitectura del verso. En este estudio, su nombre aparece junto a Julián Marchena, Isaac Felipe Azofeifa, Laureano Albán y Marco Aguilar, entre otros.

11. El investigador rescata el aporte de Ángel Rama y su propuesta para que el corpus de la literatura de América Latina no sea medida con la vara rígida de una historiografía literaria lineal que se distancia del verdadero escenario que presentan los procesos culturales.

12. Las voces de los otros ocho poetas destacados en el estudio son: Francisco Luis Bernárdez, José Miguel Ibáñez Langlois, Ernesto Cardenal, Pedro Casaldáliga, Joaquín Antonio Peñalosa, Gabriela Mistral, César Vallejo y Nicanor Parra.

13. En el ámbito intertextual el autor explica que el aspecto intimista en Debravo recuerda la poesía de César Vallejo; el religioso-social a los poetas de la Teología de la Liberación; el franciscanismo es asociado con Peñalosa y Gabriela Mistral y lo erótico-sexual con la poesía de Vallejo y Ernesto Cardenal.

14. Como ejemplo, se recuerda que en el universo poético de Debravo es reiterativo en el uso del vocablo "hueso" o su plural "huesos". La osamenta se asocia con la mortalidad y por lo tanto con el dolor. En este sentido, Martínez establece un vaso comunicante con el arte vallejiano. Otras partes del cuerpo que contienen una fuerte carga simbólica y que comúnmente son resaltadas en el arte de Debravo son los ojos y las manos. 


\section{Bibliografía}

Baeza Flores, Alberto. 1978. Evolución de la poesía costarricense. San José: Editorial Costa Rica.

Brenes Papayorgo, Magda. 1990. Jorge Debravo, legitimación y permanencia. Tesis de maestría no publicada. Universidad de Costa Rica.

2007. "La intertextualidad en la poética de Jorge Debravo". En: Revista Comunicación. Vol. 16 Ed. Esp. San José, Costa Rica.

Bonilla Baldares, Abelardo. 1981. Historia de la Literatura Costarricense. San José: Universidad Autónoma de Centro América.

Calvo Fajardo, Yadira. 1980. Poesía en Jorge Debravo. San José: Ministerio de Cultura, Juventud y Deportes.

Chase, Alfonso. 2000. El amor en la poesía costarricense. 1 edición. San José: Editorial Costa Rica.

Chen Sham, Jorge. 1996. "La silenciosa incertidumbre de la lira costarricense: un acercamiento a su proceso de recepción." En: Revista de Filología y Lingüistica. Vol. XXII (2), julio-diciembre, San José, Costa Rica.

Chen Sham, Jorge. 1998. "La buena noticia para los hombres: las bienaventuranzas según Jorge Debravo." En: Revista Káñina. Rev. Artes y Letras, Univ. De Costa Rica. Vol. XXII (1), San José, Costa Rica.

Debravo, Jorge. 1981. Antología Mayor. San José: Editorial Costa Rica.
Duverrán, Carlos Rafael. 1973. Poesía contemporánea de Costa Rica. San José: Editorial Costa Rica.

Martínez Fernández, Juan Manuel. 2003. Tres caminos y nueve voces en la poesía religiosa hispanoamericana contemporánea. Tesis Doctoral. Universidad Complutense de Madrid. Extraída el 20 de diciembre de 2009 desde http://www.ucm.es

Monge Alfaro, Carlos Francisco. 1991. Códigos estéticos en la poesía de Costa Rica. Tesis doctoral. Universidad Complutense de Madrid.

1992. Antología crítica de la poesía de Costa Rica. San José: Editorial Costa Rica.

2009. Territorios y figuraciones. Heredia, Costa Rica: Editorial Universidad Nacional.

Montanaro Meza, Óscar. 2007. "La vigencia poética de Jorge Debravo." En: Revista Comunicación. Vol 16 Ed Esp. San José, Costa Rica.

Ortiz, María Salvadora. 1987. "La fraternidad del yo lírico en canciones cotidianas de Jorge Debravo." En: Revista de Filología, Lingüistica. Vol. XIII (1).

Retana, Edmundo. 2006. "Imágenes liberadoras de Dios en la poesía de Jorge Debravo." En: Pasos, N. 125. DEI, Departamento Ecuménico de Investigaciones, San José: Costa Rica. Extraído el 20 de diciembre del 2009 desde http://www.dei-cr.org/

Rodríguez Cascante, Francisco. 2006. "La formación discursiva trascendentalista en la poesía costarricense contemporánea." En: Revista de Filología y Lingüística. XXXII (2). 
2006. "La poesía costarricense contemporánea y el campo discursivo conversacional". En: Káñina, Revista de Artes y Letras, Universidad de Costa Rica. XXX (2).

. 2007. "La poesía de Jorge Debravo y el pensamiento humanístico". En: Revista Comunicación. Vol 16 Ed Esp. San José, Costa Rica.

Rojas, Margarita y Flora Ovares. 1995. 100 años de literatura costarricense. San José: Ediciones Farben.
Sandoval de Fonseca, Virginia. 1978. Resumen de la Literatura Costarricense. San José: Editorial Costa Rica.

Valdeperas, Jorge. 1991. Para una nueva interpretación dela literaturacostarricense. San José: Editorial Costa Rica.

Zúñiga, Francisco. 1979. El soneto en la poesía costarricense. San José: Editorial Costa Rica.

\section{() $(\Theta \Theta \Theta$}

Este obra está bajo una licencia de Creative Commons

Reconocimiento-NoComercial-SinObraDerivada 4.0 Internacional. 
